\title{
Modernising Violence and Social Change in the Spanish Sahara (1957-1975)
}

Enrique Bengochea Tirado and Francesco Correale*

enrique.bengochea@fcsh.unl.pt ; francesco.correale@univ-tours.fr

Publicado como: Enrique Bengochea Tirado y Francesco Correale: "Modernising Violence and Social Change in the Spanish Sahara (1957-1975)”, Itinerario (2020) DOI: 10.1017/S0165115320000042.

\begin{abstract}
:
In Spain’s last colony, Western Sahara, both efforts by the colonial power to stimulate development and the negative impacts of colonisation intensified between the end of the Ifni-Sahara War (1957-58) and the Spanish withdrawal in 1975. Spanish economical and geopolitical interests triggered an important industrial and urban development of the territory. Cities such as Laayoune, Villa Cisneros, Smara, and the Bou Craa phosphate deposits were to showcase Spanish modernising colonial policies.
\end{abstract}

However, the effects of war, the control of colonial frontiers, and severe droughts during the 1960s strongly affected Sahrawi society. In this context, the Spanish colonial state developed new forms of control over the Sahrawi population, which included the progressive (forced) settling of nomadic people around military posts and Spanish cities, bringing about the adoption of new economic paradigms. Not only did the Francoist government distribute subsidies, both money and goods; it furthermore implemented policies aimed at controlling the Sahrawi way of life, particularly in the areas of hygiene, education, and gender relations. The essay analyses these "carrot-and-stick" strategies at the intersection of colonial control and forced sedentarisation with regard to the implementation of a market-oriented economy in Western Sahara.

Keywords: Western Sahara, Spanish colonialism in Africa, Ifni-Sahara War, Sección Femenina, social and economic changes, Sahrawi nationalism 


\section{Introduction}

An oft-repeated saying used throughout the dictatorship of Francisco Franco in Spain described the Sahara as a province so Spanish that it rivalled the likes of Cuenca, Cádiz, or Santander. ${ }^{1}$ The expression has been attributed to both colonists and key figures in Franco’s dictatorship, such as General José Díaz de Villegas y Bustamante or Admiral Luís Carrero Blanco, both of whom had strong ties to colonialism in Africa. $^{2}$ A statement on the imperial project of Spanish late colonialism, it suggested that the ability to incorporate colonial subjects into the national project was enough to justify the metropole's ongoing presence in these territories. To be "a province as Spanish as Cuenca” was an implicit expression of the power of Franco's regime to modernise and bestow a Hispanic identity upon these ostensibly primitive societies.

While the intellectual roots of this justification date back to the Africanism of the nineteenth century, this particular project did not take shape until the second half of the 1950s. ${ }^{3}$ In 1958, Spanish colonies in Africa were granted a provincial status, paving the way for a number of institutional investments and renovations aimed at giving them a more metropolitan appearance. In the case of the Sahara colony, this process came on the heels of the Ifni-Sahara War (1957-58), which highlighted the lack of authority the Spanish had over the territory. ${ }^{4}$ In Western Sahara, France and Spain had fought for control over the territory and its inhabitants, combining strategies of both attraction and dominance. As a result, not only was the area divided into a series of fragmented borders, agreed upon through a number of diplomatic agreements between France and Spain at the beginning of the twentieth century, but it also saw the rise of new key figures established as intermediaries between the administration and the Sahrawi population.

After becoming a member of the United Nations in 1955, the Franco regime refused to provide a list of non-self-governing territories under Spanish control. In fact, these strategies were initially implemented with the intention of disguising the imperial, exploitative nature of the Spanish project. The majority of international actors perceived provincialisation as a crude, sensationalist strategy aimed at 
prolonging colonial power for an indefinite period of time. However, it comes as no surprise that over the years the Spanish administration gradually lost the support of its most important allies, such as the French government. Meanwhile, the internal workings of the dictatorship saw various sectors becoming more open to processes of decolonisation, in exchange for greater integration into the international community. In addition, beginning in 1955-56, the Kingdom of Morocco, which had gradually begun repairing strained relationships with its neighbours, included the Sahara as one of the territorial claims detailed on the map of "Greater Morocco" distributed by leaders of the Istiqlāl political party. ${ }^{5}$

The Spanish strategy was to mimic the decisions made under the Salazar dictatorship in Portugal, which had reformed its constitution in 1951 amid mounting pressures to decolonise, amending the status of its colonies to "overseas provinces." These were related projects, in which the economic transformation of the provinces was accompanied by a cultural framework typical of Iberian dictatorships. ${ }^{6}$ Beyond appearances, both projects responded to what has come to be known as "the second occupation,” in line with the parallel processes geared towards intensifying public investment in development programmes that took place during the late colonial period. Just as the French and British empires had been doing since 1945, imperial rule was rekindled through increased political control under the guise of modernisation, as well as by co-opting traditional male elites through financial support and donations. $^{7}$

This was a process similar to previous models of colonial domination, but with redoubled efforts to build infrastructures and identify supposedly suitable social models, such as paid work or the relegation of women to the domestic sphere. In this sense, the influence these policies had on gender relations became an interesting indicator. Both the Iberian empires and their British or French counterparts sought to transform the role of women in society with institutions meant specifically for them. At the same time, colonial contact brought with it the increased importance of male roles in colonised societies: men mediated between colonial institutions, thereby assuming greater power and responsibility that they had not had access to previously. ${ }^{8}$

These transformative processes were not without violence. The participation of the local Saharawi 
population became possible only after extensive social fragmentation, at least to a certain degree. The indiscriminate bombing during the Ifni-Sahara War had disastrous consequences for the livelihoods of pastoral nomads. These consequences (destruction of pastures and wells, obstacles to trans-Saharan trade) opened the door to Spanish authoritarian social engineering, including policies of sedentarisation. The introduction of wage labour, limiting women's roles to those within the home, and the establishment of physical borders would not have been possible without the arbitrary use of power and repressive police control.

Nevertheless, co-optation strategies also played an important role in this process. Sheikhs ${ }^{9}$ steadily lost power as the colonial administration continued to alter the context within which their role had developed. However, the colonial administration gave these individuals an important role as intermediaries, thus creating a new class of notables who depended on the government to maintain their economic and social status. Sheikhs participated in the provincial government, both in local and regional institutions, as well as in the distribution of social benefits amongst the Saharan population. Of course, this was all under the watchful eye of the metropolitan government, which always had the final say in any decisions. ${ }^{10}$

This article seeks to analyse these processes of repressive development, linking the social transformations that took place in the Sahara from 1957 to 1975 with the uses and abuses of state power, which often blurred the boarders between cultural repression and open violence. ${ }^{11}$ We shall begin by examining the Ifni-Sahara War and its consequences: this was a crucially important event in the region’s social and cultural history, although scholarship has focused so far only on the military aspects. ${ }^{12}$ Further on, we provide an analysis of the "provincialisation" of the colony, examining both the physical and institutional transformations of the territory. Finally, we will consider a number of social groups that did not form part of the regime’s co-optation, exploring the interplay between modernisation, social changes, and exclusion, all of which have been influenced by the “colonial situation” and its inherent violence. ${ }^{13}$

We contend that violence-whether in open warfare or in its shadow—constitutes the primary condition and consequence of any colony. It seems paradoxical to talk about military "pacification” or 
"peaceful penetration" when colonialism has always entailed the control of a few over many, the exploitation of a population's resources, the disintegration of its social balance and political traditions—in short: the indiscriminate use of direct or indirect violence to impose a political or social order alien to those societies. By relating the 1957 war to subsequent processes of "modernisation” and social changes until 1975, we seek to highlight the violence of a period that has largely been ignored by academia. ${ }^{14}$

\section{Ifni-Sahara War}

During the 1950s, the Spanish-ruled Saharan territory formed the epicentre of a number of military operations carried out by Spanish and French soldiers in an effort to expel what was known as the Army of Liberation. Formed in 1953-54 by irregular troops from the rural and mountainous zones of Morocco, it had become the main actor in the fight against the French Protectorate. ${ }^{15}$ While part of the Army of Liberation joined the Royal Armed Forces after Morocco had won its independence, several contingents avoided incorporation into the new Moroccan army and established their command headquarters in the south, in the city of Guelmim. Later, in 1955, during a time of complete political uncertainty, the Army of Liberation launched a series of strategic incursions into the territories still under Spanish rule.

Beginning in October of 1956, contingents of the Army of Liberation moved into Spanish colonial territory. They had managed to obtain consent from Franco’s government after expressing their willingness to only attack the Mauritanian and Algerian territories, both of which were under French rule at the time. In fact, in June and July 1956, the Army of Liberation carried out two attacks against French positions in Algeria, and in January and February 1957, two more took place against positions of the same army in Mauritania. ${ }^{16}$ Although these incursions ultimately failed, the army also made a concerted effort to proselytise, which proved to be quite successful in the region of Ifni, where they received massive support from the Ait Baamrane tribe, and in the Sahara, where recruitment took place from family to family in the name of jihad against the colonial occupation. Despite ample signs of these groups' eventual intentions of recovering these territories, Spanish authorities ultimately chose to ignore them. 
That said, in the summer of 1957, relations between the Army of Liberation and Spanish authorities rapidly deteriorated. The latter decided to withdraw all European soldiers from inland positions, including the Ifni and Saharan regions. The Army of Liberation swiftly took advantage of the movement, occupying the deserted positions one by one. On 23 November, colonial troops were surprised in a coordinated attack on the city of Sidi Ifni, capital of the Ifni region. On that day, as several battalions of the Army of Liberation besieged the city, people throughout the whole territory rose up against the colonial power. As a result of their ill-fated movements, by the time the 1957-58 winter approached, the Spanish army controlled only the urban centres on the coast. Meanwhile, the Army of Liberation, which had between seven and eight thousand soldiers by the summer of 1957, had secured the inland positions. ${ }^{17}$

After lengthy negotiations between the Spanish and French governments, a series of large-scale military operations were launched in January 1958, in an effort to expel the Army of Liberation from the Saharan and Ifni territories. These operations, referred to as Écouvillon by the French and Teide/Huracán by the Spanish army, involved bombing both Army of Liberation contingents and nomadic camps suspected of supporting the "rebels” in the Sahara, including settlements' livestock and wells. ${ }^{18}$

After the formal end of military operations, the government in Madrid ceded Tarfaya, the southern area of the Spanish protectorate, to Rabat on 2 April 1958. The city of Ifni itself became a Spanish enclave, until it was retroceded to the Alaouite kingdom a decade later on 30 June 1969. Both the Sahara and the Ifni settlement were rebranded as new "metropolitan provinces" on 10 January 1958, thereby avoiding labelling the territories as colonies, a status that was confirmed three years later with Act 8/61 of 19 April 1961. This measure enabled Franco's government to promote the colonisation process despite the growing global trend towards decolonisation.

Although the way in which the Ifni-Sahara War was managed implies a certain level of complicity between the Moroccan and Spanish governments, given the government of Rabat sustained silence throughout the Franco-Spanish military operations, the end of the war did not see the territories successfully reclaimed as per the proposed map of Greater Morocco made official by the nationalist party Istiqlāl in 1956. ${ }^{19}$ Throughout the second half of the 1950s and the first half of the 1960s, these claims to 
territory were mainly focused on Mauritania and Algeria, leading to the so-called Sand War (Guerre des sables o Jarb ar-rimal) against Algeria in $1963 .{ }^{20}$ Mauritania's independence was recognised by the Rabat government in 1969, creating great political friction between the monarchy and the Istiqlāl party. These Moroccan territorial demands formed part of the broader political conflict that had ravaged the Kingdom of Morocco since its independence; they had also been used to help ease the strong social uproar that had characterised the country since the mid-1960s. ${ }^{21}$

While territorial disputes had a larger impact on the Spanish government’s Saharan policies, they were not the only issue of concern for the colonial administration. The most important internal concern came from attitudes on the part of the territory's population, who, having already had a taste of the power that jihad had lent them from 1956 to 1958, once again found themselves subjugated to colonial rule. With the return of colonial rule came its inherently violent power structures.

First, there was the propaganda that Istiqlāl distributed through its offices in Villa Bens, Laayoune, Smara, and Villa Cisneros, as well as Ifni; these offices had been open since the Kingdom of Morocco gained its independence, but they were all closed once the Army of Liberation's actions intensified. Second, many men took active part in the armed struggle against the army from within the territory, rendering more than necessary the development of a policy that could offset any possible nationalist sentiments among those who no longer accepted a colonial administration in the Sahara. Thus, the Spanish colonial administration was forced to take action, not only to allow it to remain in the region, but also to legitimise the Spanish presence there in the eyes of the people and, by extension, justify that presence with respect to overarching Moroccan ambitions and the prevailing wave of decolonisation sweeping the Maghreb. In this postwar setting an often contradictory colonial policy combining incentives and coercion evolved, which coined Spain’s repressive developmentalism in Western Sahara until 1975. 


\section{The Spanish Response and Postwar Policies to Attract Notables}

Following Spain’s entry into the United Nations in 1955, it was bound by Chapter XI of the UN Charter to disclose any non-self-governing territories under its rule. By deeming them provinces, the Spanish government sought to get its African colonies off the list of non-self-governing territories. This tactic did not prove to be successful. The UN continued to insist that Spain decolonise its "African provinces," with the Moroccan government staunchly backing this initiative from its inception. Faced with mounting pressure, the Franco regime responded in an ambiguous manner, attempting to prolong its presence in the territory for an indefinite period of time. Although the Spanish government eventually supported resolutions calling for decolonisation of the Sahara, the territory saw a number of new policies that served to intensify colonisation, showcasing the imperial repertoire of different but concurrent strategies of domination..$^{22}$

These policies had major repercussions for the people of the Sahara when the colonial power attempted to win some of them as supporters of the Spanish presence in the territory. One of the administration's first actions was to create harkas (militia contingents) on the northern border, made up of irregular Sahrawis who, while not officially part of the Spanish army, fell under its command. The aim was to intensify rivalries between the different tribes in the south of Morocco and create a climate of insecurity. These harkas, organised on a tribal basis, were different from the battalions of the Army of Liberation in that they were entrusted with carrying out incursions, especially within the region of Tarfaya and its surroundings. The Spanish forces were assisted at the time by the French forces of Mauritania, who created "partisan" militias in the region of Adrar at the border with the Spanish-ruled Sahara, to support French opposition to Morocco’s territorial claims to Mauritania. ${ }^{23}$

Additionally, in an effort to assuage the frustrations and discontent of people who had just undergone the most turbulent months in the territory's contemporary history, the Spanish government decided to reimburse the damages caused in the conflicts of 1957-58. Remunerations covered the 
destruction caused by military actions of both the Army of Liberation and the French and Spanish militaries; casualty lists were drafted, including hundreds of names, and were constantly updated at the request of notables who demanded money from the government. Victims were directly compensated not only for the death of family members but also for the destruction or loss of livestock, provisions, or personal possessions. ${ }^{24}$ These sums were granted over a period of time dating back from spring of 1958 to the mid-1960s. ${ }^{25}$

Most revealingly, the greatest consensus mechanisms put into place to entice the local population were known as “social assistance.” These benefits involved material aid that was provided by the Francoist government, beginning at the end of 1959, in response to requests from the population prompted by the intense droughts affecting the territory and the subsequent loss of pastureland. By gaining the loyalty of the inhabitants of the "new province," the Spanish government managed to shield the population of the territory from possible Mauritanian or Moroccan influences that may have otherwise bolstered a rise in anti-colonial sentiments amongst Saharawi, as had already occurred during the IfniSahara War. In 1959, the governor of Spanish Sahara anticipated a total amount of about 1.3 million pesetas in food aid, in addition to over six hundred thousand pesetas for distribution in cash, as a “reimbursable” advance. This money came from the Spanish state, as the province did not have sufficient funds; it had to be increased, with an extraordinary credit of some 6.4 million pesetas designated for “social action expenses.” This amount made up 12 percent of the total budget of 53.5 million pesetas allocated to the province in 1960. This extensive assistance programme was continually renewed throughout Spain's presence in the region until 1975. ${ }^{26}$

Nevertheless, these social benefits were not handed out equally: their distribution fell largely into the hands of the sheikhs, who often favoured their own families and clientelistic networks. In other cases, the colonial administrators themselves organised the distribution of benefits via patrol groups whose routes reached the most isolated corners of the "Saharan provinces." This enabled the surreptitious creation of a mechanism for surveillance, control and reconnaissance of local populations, especially those that had not yet been settled in urban centres on the Atlantic coast, such as Laayoune or Villa 
Cisneros. Furthermore, the notables who managed the distribution of benefits occasionally illegally appropriated funds, channelling them into the informal trade routes that wound their way from the Sahara to Algeria, Morocco, and Mauritania. In this sense, Spanish colonialism created members of a new upper class, thereby guaranteeing their cooperation as intermediaries between the provincial government and those without direct access to the administration. Spain's paternalistic welfare colonialism with its new cooperation networks contributed to further political and tighter social control throughout the territory.

\section{Territorial Exploitation and Institutionalisation of the Colony during the Period of Provincialisation}

Parallel to the enticement strategies implemented through remunerations and social benefits, and in accordance with the establishment of the territory as a province, the colonial government implemented an intense modernisation policy. This consisted of establishing industries for the economic exploitation of natural resources; developing an entire institutional apparatus to legitimise and justify Spain’s presence; and expanding urban centres to accommodate the population which Spanish colonial rule sought to sedentarise. The Spanish official "colonial mind” considered the nomadic way of life as something from another time, as an obstacle with regard to the territory’s “modernization” and “development.”27

The colony’s main economic interests lay in taking advantage of its mining resources. This exploitation moved slowly, due to the lack of infrastructure. In 1947, important phosphate deposits were discovered in Bou Craa, near Laayoune. However, it was not until the 1959 hydrocarbons law that the area was fully investigated. In 1964, the government-funded company ENMINSA constructed permanent facilities in the mines and moved a large number of workers to the site. ${ }^{28}$ Eventually, a hundredkilometre-long conveyor belt was installed, connecting the mine site to the sea via a dock that allowed freighters to offload raw materials. The Spanish company Fos Bucraa was formed in order to further exploit the local resources, showcasing Spanish stimulation of the Saharan economy at home and abroad. $^{29}$ 
Another resource that caught the colonial power's attention were the fishing grounds shared with the Canary Island coasts. Fishing was an important source of capital attraction, and it was of special interest to islanders concerned about securing the African coasts for their own factories. The economic interests shared with the Canary Islands did not end with fishing; by the second half of the 1960s, a growing number of tourists staying in Gran Canaria or Tenerife began to show an interest in visiting Laayoune and Villa Cisneros. The National Parador of Laayoune, ${ }^{30}$ opened in 1969, was the most characteristic example of the Spanish government's attempt to incorporate its African colony into the rising surge of tourism, which played an increasingly important role in the country’s economy.

Economic investments, alongside the institutional developments that came with this new era of colonisation, brought a relatively important contingent of Spaniards to Western Sahara. To the traditionally military population were added civilians, such as military family members who arrived along with the increased development of education and health services, especially in bigger urban centres such as Laayoune and Villa Cisneros. The civil servants in charge of these services contributed to the growing European population in the Sahara. ${ }^{31}$ Finally, mining companies attracted a certain number of skilled labourers, in addition to the fishing industry and the possibility of providing services, all of which served as incentives for joining the expanding colony from the Canary Islands.

In the new urban centres, the recently arrived metropolitan population encountered pastoral nomads. The latter were forced to turn to the former for assistance, due to the economic destruction (of livestock and pasture) suffered as a result of the Ifni-Sahara War, and attracted by the resulting ease of access to benefits provided by the colonial government. Laayoune, Villa Cisneros, and Smara were surrounded by neighbourhoods made up of a combination of jaimas, the nomads' traditional tents, and self-built huts, inhabited mainly by Sahrawis. The sudden growth of these cities posed a genuine housing crisis that the Spanish administration first attempted to solve in 1963. It was in this year that the National Institute of Housing (Instituto Nacional de Vivienda) $)^{32}$ began intervening by implementing a major construction plan. Construction continued throughout the 1960s and continued to expand into the 1970s with the creation of neighbourhoods such as Colominas around Laayoune. These new buildings were 
planned according to the inhabitants that they were to receive, depending on whether the latter were soldiers, civilians, or Sahrawis. ${ }^{33}$

Additionally, the province was organised around an institutional duality. The Decree of 14 December 1961 established a legal regime for the province that, while drawing inspiration from the state's fundamental laws, had to take into account the characteristics and peculiarities of the territory. A number of traditional, Sahrawi-led institutions were proposed, including the Yemáa, the Saharan general assembly, and sharia law, a legal system inspired by the common law of the nomad society. A wide range of services were organised by the Presidency of the Government in Madrid, which had authority over the "new provinces” and its dependants, and ultimately by the General Government of the Sahara, controlled by high-ranking military officers; it was these bodies that would make any de facto decisions. Alongside these institutions at the local level was a series of bodies inspired by the Francoist "organic democracy" that combined representation of the Sahrawi and metropolitan populations within the limited dictatorial political framework.

Amongst the services controlled by the General Government were the treasury, justice, education, health, public works, architecture, mines, telecommunications, work, information, and security. In addition, hospitals, primary and secondary schools, and other public buildings were created over time and incorporated into the urban centres, mainly serving the interests of the newly settled metropolitan population. Regarding health services, for example, there were four centres in 1953, which had grown to twenty-five by 1972, thus adequately covering the needs of the urban centres (but not of rural areas, that is, the desert). ${ }^{34}$ The majority of educational services were primary schools, but there were also secondary schools in Laayoune and Villa Cisneros, as well as the boarding school (escuela-hogar) for children in Laayoune and the Sección Femenina centres for women in Laayoune, Villa Cisneros, and Smara. ${ }^{35}$

The Sección Femenina and its schools and centres revealed the gendered aspects of new institutions in the Sahara. ${ }^{36}$ The Francoist-inspired Falangist organisation was in charge of helping women find their niche within the dictatorship, as well as providing education, health, and political services. ${ }^{37}$ Its main area of influence was in Laayoune, which hosted a girls' boarding school, textile cooperative, 
women's centre, and a recreational activity group for girls (which also organised activities in Villa Cisneros and Smara). These services were primarily aimed at Sahrawi women who had settled in the urban centres, teaching them what were considered essential tasks for women, such as cooking, cleaning, and childcare. The colonial administration used these activities to firmly link Saharawi women's education to the concept of how to run a household in the newly built settlements in the suburbs.

Although the majority of these efforts were aimed at equipping women with the skills needed to properly manage their new homes, housework was far from the Falangist regime's main concern. It wanted to prepare women for those jobs considered well suited to them, with the ultimate goal of incorporating them into the cycle of production and consumption. ${ }^{38}$ It also sought to include women in the national project, thereby showcasing the ostensible inclusivity of Spanish imperialism. ${ }^{39}$ Finally, over time, the Women's Section sought to enlist the help of some of these women in maintaining its power throughout the Sahara, an effort that was met with great resistance. ${ }^{40}$

As regards the governmental institutions in which Sahrawis participated, the local level was of primary importance. Four urban centres were established: two as municipalities (Laayoune and Villa Cisneros) and two as smaller local entities (Smara and La Güera), whose representatives were chosen following the principles of the so-called organic democracy. In this way, voting rights were granted to male heads of household residing in any of the aforementioned urban centres. However, only half of these advisers were directly elected; the other half was selected from amongst representatives of commerce, industry, the cultural sector, and professions, most of whom were Spanish. The same was true of the provincial council, which was established by the provincial government and composed of a president, a vice-president, and fourteen councillors. Two of these councillors represented town halls and small local entities, six represented the nomadic divisions, and the remaining six represented different sectors. ${ }^{41}$

The province of the Sahara also had three representatives in the Francoist courts, chosen by the government from amongst its most influential members. In 1963, the three representatives were the mayors of Laayoune and Villa Cisneros and the president of the provincial council. By 1967, the number of representatives in the courts had increased to six, two of whom were chosen among heads of 
household, with the remaining four appointed by the government. The participation of Sahrawi representatives in the court system served the colonial administration by legitimising Sahrawi participation in the other, wholly undemocratic institutions of the dictatorship.

Finally, we should also mention the Yemáa, or general assembly, a "traditional” institution that served as a provincial representative body. Its members were elected for the first time in 1967 and again in 1971 according to the regime’s organic principles. ${ }^{42}$

The introduction of all of these instruments of governance and domination demonstrates how the Francoist dictatorship exploited the disruptive consequences of the war to completely transform both the territory and the people's social ways of life. The institutional framework was meant to justify and complement a modernisation project that ultimately aimed to incorporate the colonial territory into the dictatorship’s extractive logics. This, in turn, was based on a series of standards imported from the metropole, which sought to transpose peninsular social, gender, and political models that clashed with the previous forms of life in the colony. Imposition of Spanish culture, including a sedentary way of life, was meant to ensure social stability.

\section{Social Changes during the Late Colonialism of the Sahara}

Within the territory, colonisation brought with it increasing social and economic authority of notables who found themselves newly empowered through their dealings with the colonial metropole. ${ }^{43}$ Once traditional tribal warfare paradigms had shifted, sheikhs quickly adapted their roles to become

intermediaries between the pastoral society and the colonial administration. ${ }^{44}$ This historical process, in which the system of social benefits played a highly relevant role, led to a sharp increase in the number of dignitaries. ${ }^{45}$ The development of an administrative structure in the Sahara province saw their political and economic power institutionalised; mayors, legal representatives, and members of the Yemáa were all chosen from amongst this new social elite.

It is easy to see why anthropologist Rita Laura Segato has labelled this a "hyperinflation of male 
status," a process by which the role of men in colonial societies as liaisons with the colonial power led to the inevitable creation of a male-dominated, privileged public sphere. ${ }^{46}$ The process influenced gender relations in these societies, enabling the formation of an alliance between colonised male elites and the colonial power, to the detriment of women. Once power structures such as sharia law, sheikhdom, or the Yemáa had been institutionalised, any influence women had held in precolonial society was steadily eroded. Moreover, the few societal opportunities the colonial administration did offer women, for example through the Sección Femenina, forced them to accept certain aspects of urban life that ensured continued female subalternity within the public sphere and stressed the importance of women's attachment to the home.

In this manner, the Yemáa launched an attempt to control the price of dowries in 1971. Amongst the military documents found in the general military archives of Ávila are complaints from several youths describing themselves as "successful young elites” (a post office civil servant, Saharan radio announcer, and merchant), who noted with dismay the high dowries fathers demanded for their daughters, especially for those who formed part of the Sección Femenina. In addition, it was also reported that "at the General Assembly, the sheikhs have drafted a document aimed at limiting dowries, but it is not respected, as in Morocco dowries are even cheaper and women are better equipped to run a household.”47

A number of dynamics can be observed in this complaint: first, the effects of differing dowry prices in Tarfaya and the territory controlled by Spain; second, recognition of the value of women who had acquired certain skills, such as the ability to run a household; and, finally, the willingness of the sheikhs represented in the Yemáa to interfere in marriage negotiations. ${ }^{48}$ This particular dynamic traditionally involved the entire family group, leading to the creation of sororities that united women from different families. ${ }^{49}$ The legislation bypassed the tools women had previously used to contend with their inferior status in the colonial context.

This was not an isolated attempt to control the marriage market. Notables represented in the Yemáa also sought to control divorces, through which women could request a separation from their husbands, who were subject to certain social pressure to accept. ${ }^{50}$ The following is a complaint filed with 
the inspector of the Sección Femenina in autumn of 1974:

A former student told us she had secured a divorce from her husband at her own request, via payment of two hundred and fifty thousand pesetas. This unprecedented case (which was immediately followed by another) is in accordance with a decision taken at the Yemáa on 4-5-74, which reads as follows:

Any married woman who rejects her husband is bound to either choose to carry on living with her husband at their home of residence, or give him FIFTY THOUSAND $(50,000)$ DUROS in Spanish currency. Should this amount be paid, the husband is then obliged to divorce his wife.

Women insist that the Yemáa's decision should be reconsidered, as this situation negatively affects them. The Koran establishes that dowries should be returned. ${ }^{51}$

Once again, the privilege granted to men by the colonial administration allowed them to circumvent the traditional means by which Sahrawi women could negotiate their position within the family. These cases demonstrate how a certain class of women formed yet another social group marginalised by colonisation. The male empowerment brought about through the institutionalisation of certain decision-making forums destroyed some of the tools women had previously used to engage on key issues such as marriage. ${ }^{52}$

The structures proposed by the Spanish administration as new channels of female representation proved ineffective. It is worth noting here the inability of the sole Francoist women's organisation, the Sección Femenina, to organise itself in the face of demands made by Sahrawi women, such as calling for their assistance in battling attempts to control marriage on the part of the Yemáa. For the colonial administration, the role of the state was to guarantee women's access only to very specific training and education, equipping them to bear children and limiting them to very specific niches within the labour market, thereby imposing colonial gender roles. ${ }^{53}$ Moreover, issues related to family rights, such as dowries or age of marriage, were considered private matters in which the institution had no right to interfere. $^{54}$ 
On another note, the process of monetisation seen in this phase of colonisation should also be highlighted. This phenomenon was linked to an increase in the importance of wage labour and the creation of a labour market. Investments originating in the metropole increased starting from the midtwentieth century, leading to inflation and providing some limited opportunities for Sahrawi entry into the market economy. In this respect, the role of the Spanish state as an investor was essential, promoting large mineral extraction companies such as Fos Bucraa, as well as constructing infrastructure including roads and homes and promoting industrial activities such as fishing and tourism.

In contrast to these economic phenomena, which were more significant within urban areas, traditional nomadic practices were under threat. ${ }^{55}$ The result was a dual economy that nonetheless maintained a certain continuity. This was reflected in the distribution of occupations amongst the different areas of the province found in the 1974 census. ${ }^{56}$ Although the majority of those surveyed appeared to not have an occupation, those who did worked primarily as farmers or labourers, followed by soldiers, merchants, and drivers. ${ }^{57}$

Both farming and labouring work involved a kind of nomadism, as pointed out in the 1974 census: "The creation of jobs on tracts of land that are currently being built or repaired also gives rise to the slow displacement of many families from one area to another." 58 Similar patterns can be observed in the case of drivers. In contrast, people who traditionally served in the military could often be traced back to prestigious families. ${ }^{59}$

The colonial regime's emphasis on wage labour and generating jobs strengthened the position of the sheikhs, who were able to insert themselves into the process as intermediaries. Meanwhile, this growth also opened up new job vacancies for qualified young workers. However, the skilled jobs and positions of political responsibility that the dictatorship was able to generate were restricted by a need for political control and economic profitability. Thus, sheikhs in privileged positions limited the prospects of youths who had to face an increasingly full administration. It should be noted that in 1966, 51 percent of the province's population were under twenty years of age, making this a crucially important demographic. ${ }^{60}$ 
When defining spaces of social transformation in the period of provincialisation, the increasingly important urban phenomenon must be emphasised. Urban centres were appealing to those who had dealt with the effects of the 1958 war $^{61}$ and the long-term droughts of $1958-1969$ and $1973-1975 .{ }^{62}$ If the Spanish anthropologist Caro Baroja described society in the mid-1950s as preeminently nomadic, ${ }^{63}$ observers in the 1970s would characterise the decade by its seemingly unstoppable wave of sedentarisation.$^{64}$ It is within this context that the relatively important urban centres of Laayoune or Villa Cisneros figured prominently. ${ }^{65}$ However, there were also a number of areas that, although sparsely populated from a quantitative standpoint, underwent a qualitative change in levels of nomadism, which had prevailed in the area just a quarter of a century before; urbanisation within the territory grew to over 55 percent, with some sources even citing an urbanisation rate of 82 percent.

The city became a space characterised by a certain possibility of accessing the market-based economy, as expressed in many poetical controversies of the time. ${ }^{66}$ These poems contrasted the prevalence of nomadic life in the desert with the opportunities provided by urban life, as seen in the poems exchanged between Salama Uld Eydud and Yedehlu Uld Esid. ${ }^{67}$ The latter had moved to Laayoune, where he worked as a roofer from 1958 to 1968 before returning to nomadic life. ${ }^{68}$ In 1972 , as a result of the second terrible drought that ravaged the territory, he lost almost all his livestock and was forced to move back to the city. He wrote poems on urban life throughout this time, but they retained a certain nostalgia for his life in the desert.

Besides being a place of relative refuge, the city became a defining place in the identity of certain younger generations. Upon carrying out a study prior to the 1974 census, researcher Pablo San Martín ${ }^{69}$ noted how, when asked about their tribal origins, several young Sahrawis residing in the capital responded “politely, but proudly, that they were residents of Laayoune, Street X, Number X.” ${ }^{70}$ He argues that young people sought to challenge the traditional colonial classification system, which was based on tribe affiliation. San Martín attributed these changing attitudes to two factors: resentment against the sheikhs, whose power was now largely derived from their role as intermediaries in the service of the colonial administration, and growing disillusionment with the social and economic changes taking place 
in Sahrawi society at the time. ${ }^{71}$

Further sociocultural disruptions were a consequence of the Operation Teide-Écouvillon, with the subsequent retrocession of the region of Tarfaya to Morocco, which further fragmented the traditionally nomadic space of the Sahrawis that had once reached the limits of Wādī Dra'a. This is a highly interconnected area in which tightened borders led to a number of divergent economic processes, causing major inequalities between adjacent territories; by 1975, the per capita GDP of the Sahara colony was $\$ 2,550$, much higher than the $\$ 180$ in Mauritania, $\$ 270$ in Morocco, or $\$ 430$ in Algeria. ${ }^{72}$ Nonetheless, relations were still maintained between the different populations in the region.

Among the populations most closely linked to colonisation were the exiles who had suffered as a result of the repression of various anti-colonial movements. Ex-combatants of the 1958 war migrated from the Sahara towards the region of Tarfaya, crossing the frontier to escape Spanish oppression. The same thing occurred just over a decade later in the wake of protests in Hatarrambla, in which the first genuinely Sahrawi nationalist movement, the Harakat Tahrir (Liberation Front), was brutally repressed by the Spanish Legion in June $1970 .^{73}$ In this latter case, groups of people emigrated to settle in Zuérat (Mauritania) or in Tindouf (Algeria), establishing an anti-colonial network beyond the territory's borders.

The emergence of the Polisario Front (Popular Front for the Liberation of Saguia el-Hamra and Río de Oro) in May 1973 saw an organised anti-colonial movement demanding the creation of an independent state on Spanish colonial territory. From this moment forward, the colonial government found itself under the considerable pressure of anti-colonial sentiments, both in the form of guerrilla activity at the territory’s borders and through the genuine political mobilisation taking place from within urban centres. The growing global consensus on decolonisation presented a new opportunity for Morocco. Madrid, however, continued to provide conflicting responses. In response to demands from the Yemáa, in 1973 the colonial government began to expand the limited representative powers of Saharan institutions. A few months after this decision came the promise to make the territory autonomous, not unlike the path Equatorial Guinea had taken before its independence. However, in December of that same year, the death of Admiral Luís Carrero Blanco-a highly influential figure in the dictatorship and a staunch proponent 
of maintaining the colony at any cost— greatly weakened the proposal. ${ }^{74}$

From 1974 onwards, the Spanish government established a change of course in politics in the Sahara. With supporters of a permanent colonial presence having lost their leader, a policy of decolonisation was established for the short term, in flagrant disregard of the directives followed up until that time in the more recalcitrant colonialist settlements in the Sahara. From that moment on, the future independence of the colony was sought, favouring the emergence of a new political class capable of overseeing the process. The Sahrawi National Union Party (PUNS) was a puppet party created for this purpose in 1974. It was mainly composed of the notables who had remained loyal to Spain over the past years and who opposed the Polisario Front, which represented the Sahrawi people. ${ }^{75}$

Finally, having reached an agreement with Mauritania, in December 1974 Morocco urged the UN General Assembly to request an inquiry on the territorial statutes from the Court of Justice at The Hague. The Alaouite kingdom sought to justify the annexation of the Spanish colony in the Sahara before a selfdetermination referendum was held. However, the advisory notice issued on 16 October 1975 established that the territory of the old "Saharan province of Spain" was not terra nullius before colonisation, although it recognised that some populations had historically been linked to the Alaouite sultan, while others maintained relationships with the "Mauritanian entity.” It was in this context that the Spanish government had begun to adopt certain measures, such as carrying out a census enabling the Saharan population to express their thoughts on the self-determination referendum under the control of the UN.

However, on 6 November 1975, King Hassan II of Morocco ordered an invasion of the Sahara, known as the Green March, led by three hundred fifty thousand Moroccans. Battles quickly broke out between the Moroccan army and the Polisario Front; meanwhile, the colonial power swiftly withdrew, with agreements signed in Madrid on 14 November 1975, dividing the territory between Morocco and Mauritania. The parties involved in the armed conflict against these movements were made up of the new generation of Sahrawis born throughout the 1950s, whose lives had been tremendously affected by the social and economic changes of the period of provincialisation. It was from within this same generation that the new Sahrawi independence movement had originated, culminating in 1973 with the Popular Front 
for the Liberation of Saguia el-Hamra and Río de Oro. ${ }^{76}$

\section{Conclusions}

On 12 October 1975, the higher ranks of Sahrawi society, represented by sheikhs—including a number of representative notables from the Yemáa or the Francoist courts—surrendered their authority to the young members of the Polisario Front in Ain Ben Tili, a small military settlement on the northern frontier of Mauritania with Western Sahara. ${ }^{77}$ Beyond the fact that the Front could serve as a vehicle for the anticolonial struggle, this time against Morocco, this was a singularly revolutionary decision that disrupted the social hierarchies that had previously dominated life in the province. The gesture was particularly confusing since the sheikh authorities' power was transformed by colonial dynamics, especially during the final period from 1958 to 1975.

In this manner, one might question whether this revolutionary act was aimed at tackling the colonial hierarchies or at subverting the traditional order. ${ }^{78}$ Throughout this text we have seen how the colonial power propped up certain notables, fragmenting the traditional society and displacing a large number of people. However, though this dynamic had intensified after 1958, it had marked Western Saharan society since the nineteenth century. In this sense, it is not surprising that these events could be interpreted as an attack on the colonial order.

Tackling the effects of colonisation that had harmed Sahrawi society meant the implementation of policies that fully encapsulated the various threads of current discourse, both in precolonial practices and the revolutionary traditions of the time. ${ }^{79}$ Thus, for example, women’s demands were emerging within the refugee camps. Women were able to achieve political importance in the administration of the camps, although they were not granted access to hierarchically higher positions. ${ }^{80}$ Dowries—and subsequently, the cost of divorce—-were abolished, and women were granted new educational options. ${ }^{81}$

In fact, what is scarcely taken into account is that colonisation was marked by violence, not only in the direct manner seen in the wars of 1957-58 or 1975, but also in a structural manner inherent to the “colonial situation,” as per George Balandier's definition. ${ }^{82}$ This involved the exclusion of certain 
populations, such as women, from the redistributive and security mechanisms of precolonial society, leaving them no choice but the options provided by the colonial administration. The final result was to incorporate the territory and its inhabitants to the logics of capitalism expressed via (oftentimes) forced control. ${ }^{83}$ In these transformations — as in all colonialism over the centuries—-the co-optation of certain elements of the colonised societies as “collaborators” proved necessary. However, even this intermediary class saw the formation of some important niches of resistance. ${ }^{84}$

Beyond the debate over the precolonial or traditional nature of these demands, what this study reveals is the fluidity and the dynamics of social practices, as well as the importance of the late colonial period in defining these concepts. That said, the period has been largely ignored by historiographers. The Ifni-Sahara War was covered up by the dictatorial press, ${ }^{85}$ and African provincial issues were monitored throughout the whole process, with propaganda being the only information to reach the masses. Only now has the academic community begun to show an interest in this volatile period of time. The previous lack of interest has been exacerbated by the political conflict that has been ravaging in the Sahara for four decades; ${ }^{86}$ academic research has been hampered, due to the instability of the period after Spanish colonisation. $^{87}$ If we focus on the period between 1957 and 1975, as Spanish colonisation was intensifying, we can better comprehend the social processes in the territory and relate them to the legacy of European imperialism at large.

\section{Acknowledgements}

We would like to acknowledge Andreas Stucki for inviting us to the meeting "Violence, Migration, Cooperation, and Gender. Late Portuguese and Spanish Colonialism in Africa Reconsidered,” held in Bern the 26th and 27th of November 2016, where the ideas of this article started to be worked on.

\section{Bibliography}




\section{Unpublished Primary Sources}

Archivo General de la Administración, Alcalá de Henares, Spain (AGA):

- Sección 3 (Cultura), Fondo 51.19 (Sección Femenina de Sáhara, Ifni, Región Ecuatorial)

- Sección 15 (África), Fondo 24 (Gobierno General del Sahara)

Archivo General Militar de Ávila, Spain (AGMAV):

- Sección 1.2 (Instituciones de la Administración Territorial), Fondo 1.2.3 (Capitanías y Comandancias Generales)

Real Academia de la Historia, Madrid, Spain (RAH):

- Archivo Documental de “Nueva Andadura,” Tercera Etapa, Serie Azul (NA)

\section{Published Primary Sources}

Al Fāsi, Allāl. Livre rouge avec documentaires. Tanger: Peretti, 1961.

Alonso del Barrio, Jose Enrique. Las Tribus del Sahara. Laayoune: Servicio de publicaciones del Gobierno del Sahara, 1973.

Caro Baroja, Julio. Estudios Saharianos. Madrid: ONO, 1990 [1955].

Cruz Tizón, Tony. “Encuesta pública en torno a nuestro pabellón.” Sahara, 6 June 1965.

Gobierno General del Sahara. Censo 1974. Laayoune: Servicio de Registro de Población, 1975.

Sahara, Provincia española. Madrid: Instituto de Estudios Africanos (CSIC), 1966. 
United Nations. The Report of the Special Committee on the Situation with Regard to the Implementation of the Declaration on the Granting of Independence to Colonial Countries and Peoples. New York: United Nations, 1977.

\section{Secondary Sources}

Allan, Joanna. "Imagining Saharawi Women: The Question of Gender in POLISARIO Discourse.” The Journal of North African Studies 15:2 (2010): 189-202.

Allan, Joanna. Silenced Resistance: Women, Dictatorships, and Genderwashing in Western Sahara and Equatorial Guinea. Madison: University of Wisconsin Press, 2019.

Awad, Bahía Mahmud. “Generaciones Literarias: Intelectualidad y Política en el Sahara Occidental, 1850-1975.” Les Cahiers d'EMAM 24-25 (2015): 29-54.

Balandier, Georges. “The Colonial Situation: A Theoretical Approach.” In Social Change: The Colonial Situation, ed. by Immanuel Wallerstein, 34-61. New York: Wiley, 1966 [1951].

Bárbulo, Tomás. Historia prohibida del Sahara Occidental. Las claves del conflicto que condiciona las relaciones entre España y el Magreb. Madrid: Destino, 2002.

Barona, Claudia. Los hijos de la nube. Estructura y vicisitudes del Sahara Español desde 1958 hasta la debacle. Madrid: Langre, 2009.

Bengochea Tirado, Enrique. Entrega, hogar e imperio: La Sección Femenina en la provincia de Sahara. Barcelona: Bellaterra, 2019.

Bengochea Tirado, Enrique. "Las mujeres saharauis a través de la Sección Femenina. Un sujeto colonizado.” Arenal 19:1 (2012): 143-59.

Bengochea Tirado, Enrique. Políticas imperiales y género. La Sección Femenina en la Provincia de Sahara (1961-1975). PhD diss., Universitat de València. Valencia, 2016.

Bonneuil, Christophe. “Development as Experiment: Science and State Building in Late Colonial and Postcolonial Africa.” Osiris 15 (2000): 258-81. 
Campos, Alicia and Violeta Trasosmontes. "Recursos naturales y segunda ocupación colonial del Sáhara español, 1959-1975.” Cahiers de l'EMAM 24-25 (2015): 107-29.

Caratini, Sophie. “A Propos du Mariage ‘Arabe.’ Discours Endogame et Pratiques Exogames: l’exemple des Rgaybat du nord-ouest saharien.” L'Homme 29:110 (1989): 30-49.

Caratini, Sophie. "Du modèle aux pratiques: Ambivalence de la filiation et de l'alliance chez les Rgaybat de l'ouest-saharien.” L'Homme 35:133 (1995): 33-50.

Caratini, Sophie. “La Prison Du Temps. Les mutations sociales à l’œuvre dans les camps de réfugiés sahraouis. Première partie: la voie de la révolution.” Afrique Contemporaine 221:1 (2007): 153-72.

Caratini, Sophie. Les Rgaybat (1610-1931). Paris: Harmatan, 1989.

Correale, Francesco. “Islàm, costruzioni istituzionali e 'democrazia.' Le origini storiche del Marocco post-coloniale.” Meridione. Sud e Nord del Mondo 4:1 (2006): 166-202.

Correale, Francesco. "La narración de la historia en situación de crisis. Reivindicaciones y contradicciones en la construcción memorial saharaui.” Les Cahiers d'EMAM 24-25 (2015): 15168.

Correale, Francesco. "La 'última guerra colonial’ de España y la literatura militar entre memoria y conocimiento.” In $7^{\circ}$ Congresso Ibérico de Estudos Africanos. 50 anos das independências africanas: desafios para a modernidade. Actas [Em linha], Lisboa: CEA, 2010, online: http: //hdl.handle.net/10071/2326.

Correale, Francesco. "Le Sahara espagnol: histoire et mémoire du rapport colonial. Un essai d'interprétation.” In La question du pouvoir en Afrique du Nord et de l'Ouest, edited by Sophie Caratini, vol. 1: 103-52. Paris: Harmattan, 2009.

Correale, Francesco, and Alberto López Bargados. "Rashōmon au Sahara Occidental: Perspectives, Contradictions et Défis dans l'interprétation du Conflit de 1956-1958.” In Culture et Politique dans l'Ouest Saharien. Arts, Activisme et Etat dans un Espace de Conflits, edited by Sébastien Boulay and Francisco Freire, 211-41. Igé: L’Etrave, 2017. 
Cueto, Adolfo. “Portugal y su imperio frente a la descolonización, 1945-1962.” Espacio, Tiempo y Forma 5:23 (2011): 161-200.

Dalmases, Pablo-Ignacio. El Sahara Occidental en la bibliografía española y el discurso colonial. PhD diss. Universitat Autònoma de Barcelona. Barcelona, 2013.

Darwin, John. “What Was the Late Colonial State?” Itinerario 23:3-4 (1999): 73-82.

Diego Aguirre, José Ramón. Guerra en el Sáhara. Madrid: Istmo, 1991.

Diego Aguirre, José Ramón. La última guerra colonial de España. Ifni-Sáhara (1957-1958). Málaga: Algazara, 2008.

Juliano, Dolores. La causa saharaui y las mujeres. “Siempre hemos sido muy libres.” Barcelona: Icaria, 1998.

Fernández-Aceytuno, Mariano. Ifni y Sáhara, una encrucijada en la historia de España. Dueñas: Simancas editores, 2001.

Fiddian-Qasmiyeh, Elena. “'Ideal’ Refugee Women and Gender Equality Mainstreaming in the Sahrawi Refugee Camps: ‘Good Practice’ for Whom?” Refugee Survey Quarterly 29:2 (2010): 64-84.

Fink, Liz. “Institutional Terra Non Firma: Representative Democracy and the Chieftaincy in French West Africa.” In France’s Modernising Mission: Citizenship, Welfare and the Ends of Empire, ed. by Ed Naylor, 31-58. Palgrave: London, 2018.

García, Alejandro. Historias del Sahara: lo mejor y lo peor de los mundos. Madrid: La Catarata, 2001.

Geschiere, Peter. "Chiefs and Colonial Rule in Cameroon: Inventing Chieftaincy, French and British Style.” Africa: Journal of the International African Institute 63:2 (1993): 151-75.

Gimeno Martín, Juan Carlos. “Ambivalencia y orden colonial español en el Sahara Occidental: (19691973).” Revista Andaluza de Antropología 5 (2013): 151-77.

Gozálvez Pérez, Vicente. "Descolonización y migraciones desde el África Española. 1956-1975.” Investigaciones Geográficas 12 (1994): 45-84.

Hodges, Tony. Western Sahara. The Roots of a Desert War. Westport, Conn: L. Hill, 1986. 
Isidoros, Konstantina. “The Silencing of Unifying Tribes: The Colonial Construction of Tribe and Its 'Extraordinary Leap' to Nascent Nation-State Formation in Western Sahara.” Journal of the Anthropological Society 7:2 (2015): 168-90.

Jerónimo, Miguel Bandeira. "Repressive Developmentalism: Idioms, Repertoires, and Trajectories in Late Colonialism.” The Oxford Handbook of the Ends of Empire, ed. by Martin Thomas and Andrew Thompson. Oxford: Oxford University https://doi.org/10.1093/oxfordhb/9780198713197.013.40.

Lewis, Joanna. Empire State-Building: War and Welfare in Kenya 1925-52. London: James Currey, 2000. Loomba, Ania. Colonialism/Postcolonialism. London: Routledge, 1998.

López Bargados, Alberto. Arenas coloniales. Los Awlad Dalim ante la colonización franco española del Sahara. Barcelona, Bellaterra, 2003.

López Bargados, Alberto. “El Sahara ante su espejo: poéticas del punto muerto.” Les Cahiers d'EMAM 24-25 (2015): 133-50.

Louit, Michel Ivan. Ecouvillon? Discrète opération de maintien de l'ordre franco-espagnole. Sahara Occidental 1957-1958. Paris: Marsouins et Méharistes, 2009.

MacMaster, Neil. Burning the Veil: The Algerian War and the "Emancipation” of Muslim Women, 195462. Manchester: Manchester University Press, 2009.

Marín Ferrer, Emilio. Atlas ilustrado. Ifni, Sáhara, Guinea. Ultimas colonias. Madrid: Susaeta Ediciones, 2014.

Martin-Márquez, Susan. Disorientations: Spanish Colonialism in Africa and the Performance of Identity. New Haven, Conn.: Yale University Press, 2008.

Morillas, Javier. Sahara Occidental, desarrollo y subdesarrollo. Madrid: El Dorado, 1988.

Robinson, Ronald. "Non-European Foundations of European Imperialism. Sketch for a Theory of Collaboration.” In Studies in the Theory of Imperialism, ed. by Roger Owen and Bob Sutcliffe, 117-42. London: Longman, 1972. 
Robles Picón, Juan Ignacio, et al. “La poesía saharaui en el nacimiento de la conciencia nacional.” Les Cahiers d'EMAM 24-25 (2015): 55-76.

Rodríguez Esteban, José, and Diego Barrado Timón. “Los procesos de urbanización en el Sahara español (1884-1975): un componente esencial del proyecto colonial.” Les Cahiers d'EMAM 24-25 (2015): 85-103.

Rodríguez Jiménez, José Luis. Agonía, traición, huida: El final del Sahara español. Barcelona: Crítica, 2015.

San Martin, Pablo. Western Sahara: The Refugee Nation. Cardiff: University of Wales Press, 2010.

Segato, Rita Laura. “Género y colonialidad: en busca de claves de lectura y de un vocabulario estratégico descolonial.” In Feminismos y poscolonialidad: descolonizando el feminismo desde y en America Latina, ed. by Bidaseca, Karina, 17-47. Buenos Aires: Godot, 2011.

Stucki, Andreas. “¿Españolizar desde la raíz? La formación de una élite femenina de cooperación en el ‘pequeño imperio español,’ c. 1960-1975.” Journal of Spanish Cultural Studies 17: 4 (2016): 34360.

Tejero Molina, Juan. El Sahara Español de la “A” a la “Z.” 2 vols. Madrid: Torres de Papel, 2013-2014. Torres García, Ana. La Guerra de las Arenas. Conflicto entre Marruecos y Argelia durante la Guerra Fría (1963). Barcelona: Editorial Bellaterra, 2012.

Vidal Guardiola, Lorenzo. Ifni, 1957-1958: la prensa y la guerra que nunca existió. Madrid: Almena, 2006.

Walter, Dierk. Colonial Violence: European Empires and the Use of Force. London: Hurst, 2017.

Zade, Mohammed. Résistance et Armée de Libération au Maroc (1947-1956). De l'action politique à la lutte armée, rupture ou continuité? Rabat: Haut-Commissariat aux Anciens Résistants et Anciens Membres de l’Armée de Libération, Editions Kawtar, 2006.

Zunes, Stephen, and Jacob Mundy. Western Sahara: War, Nationalism, and Conflict Irresolution. Syracuse, N.Y.: Syracuse University Press, 2014. 
* $\quad{ }^{*}$ Enrique Bengochea Tirado is a postdoctoral fellow at the CRIA in the New University of Lisbon and is interested in gender, colonial policies, and imperialism in Spanish history. More specifically, his work examines the role of Sección Femenina in the Spanish colonisation of Western Sahara. Francesco Correale has a PhD in history from the Aix-Marseille University, Aix-en-Provence (France), and works at the National Centre for Scientific Research (CNRS) of France as an Ingénieur de recherche en analyse des sources for the laboratory CITERES; he is also a member of the research group Estudios Poscoloniales: Sáhara Occidental at the Autonomous University of Madrid. He is co-responsible, with A. López Bargados of the University of Barcelona, for the project Rashōmon in the Atlantic Sahara: Memories and Places in the 'Ifni-Sahara War' (1956-1958), funded by the Gerda Henkel Foundation of Düsseldorf, and is PI of the project “Coloniality, Confinement and Order: Colonial and Postcolonial Forms of Internment in and Around the Mediterranean,” funded by MSH Val de Loire of Tours.

$1 \quad$ As reported by Tony Cruz Tizón, a journalist from the Sahara provincial weekly newspaper. See his "Encuesta pública.”

$2 \quad$ According to Dalmases, El Sahara Occidental, 487-8. However, the origin of this saying is a topic of some debate. Fernández-Aceytuno, Ifni y Sáhara, 627, attributes the saying to General Díaz de Villegas y Bustamante, inspired by Admiral Luís Carrero Blanco and Francisco Franco in 1955. However, Diego Aguirre, La última guerra colonial, 83-4, attributes it directly to Carrero Blanco, in a document dated 27 March 1957.

3 See Martin-Márquez, Disorientations.

4 Correale, "La 'última guerra colonial.",

$5 \quad$ For more on this topic, see Al Fāsi, Livre rouge.

6 Cueto, "Portugal y su imperio,” 161-200.

7 Campos and Trasosmontes, "Recursos naturales,” 107-29; Darwin, “What Was the Late Colonial State?” 73-

82.

$8 \quad$ Lewis, Empire State-Building and MacMaster, Burning the Veil.

$9 \quad$ Traditionally, the title of sheikh signified a prestigious position obtained by individuals in accordance to their age, wisdom, or legacy within a family unit.

10 This use of traditional authorities was widespread at this time among most of the remaining colonial states—or their descendants - as a counterpoint to ideas of popular sovereignty, which the Francoist dictatorship could not tolerate. See Fink, "Institutional Terra Non Firma” or Geschiere, "Chiefs and Colonial Rule in Cameroon."

11 See for a theoretical framework on the overlaps of repression and development in the Portuguese case Jerónimo, "Repressive Developmentalism” and Bonneuil, “Development as Experiment.”

12 Correale, "La 'última guerra colonial.,"

13 Balandier, “The Colonial Situation,” 34-61.

14 For an overview, see Walter, Colonial Violence.

15 See Zade, Résistance.

16 For more details see: Diego Aguirre, La última guerra colonial, 57-126.

17 Marín Ferrer, Atlas ilustrado.

18 For more details on these events, see Correale and López Bargados, “Rashōmon au Sahara occidental,” 21141; Louit, Ecouvillon?, 99-104.

$19 \quad$ During a trip to southern Morocco, Ahmed Balafredj, Minister for Foreign Affairs of the Kingdom of Morocco, declared to the press that the Army of Liberation was formed by rebellious and subversive groups that remained uncontrolled and difficult to neutralise. See Hodges, Western Sahara, 104.

$20 \quad$ See Torres García, La Guerra de las Arenas.

21 See Correale, “Islàm,” 166-202. In 1965, a state of exception was declared and parliament was suspended, while in 1971 and 1972, two attempted military coup d'états occurred.

$22 \quad$ When the Resolution 2229 (XXI) on the Sahara was voted on in December 1966, inviting Madrid to organise a referendum with the support of the UN, only Spain, together with Portugal, voted against the resolution. Later, in 1967 and 1968, Resolutions 2354 (XXII) y 2428 (XXIII) were voted on, with identical content to the resolution of 1966, but with a positive vote from Spain.

23 The issue of irregular troops at the borders has not been researched in depth until now (see FernandezAceytuno, Ifni y Sáhara, 624-7). Nonetheless, the actions of these troops are confirmed by the documentation found in the AGA and in the diplomatic correspondence from the French embassies and consulates in Morocco and Mauritania, preserved at the Centre des Archives Diplomatiques de Nantes. Further information also in the documents of the General Government of Algeria, preserved at the Archives Nationales d'Outre-Mer of Aix-en-Provence and in the documentation on the Sahrawi refugee camps in Tindouf.

$24 \quad$ It is interesting to note how everything was carefully monetised, establishing a standardised price for the death of an individual by bombing at 12,500 pesetas, according to the undated document AGA "Indemnizaciones por muerte,” 15(28), S 2270, exp. 2. Based on a letter from the General Secretary of the Province, AGA, letter of 11 
September 1958, S 2196, exp. 4, we also know the value of livestock: a camel was worth 3,000 pesetas, a goat 300 pesetas, and a donkey 1,000 pesetas.

25

26

27

As an official policy of settling nomads in urban centres was initiated.”(Instituto de Estudios Africanos (CSIC), Sahara, Provincia española, 23)

28

29

30

many more were opened later on, especially during the 1960s.

31 Gozálvez Pérez, "Descolonización," 48.

32 Organisation established by the Franco dictatorship with the aim of increasing construction of houses. This occurred in the 1950s, in an attempt to address the population crises some cities were experiencing.

33 Houses designed especially for the Sahrawi population in 1971 were meant to group families together, leaving a central space to use for any small livestock they may have had. See Rodríguez Esteban and Barrado Timón, "Los procesos de urbanización."

34 As per the table elaborated by Barona, Los hijos de la nube, 105, hospitals and outpatient clinics are mentioned, as well as centres at military posts.

$35 \quad$ Barona, Los hijos de la nube, 85.

36 See Bengochea Tirado, "Políticas imperiales y género."

37 Sección Femenina emerged as a women's organisation of the fascist political party Falange Española. After the Francoist victory of the Spanish Civil War (1936-1939), this institution was put in charge of all Spanish women in the one-party system.

38 For more details concerning the economic policy in the Spanish Sahara, see Morillas, Sahara Occidental.

39 Stucki, “¿Españolizar desde la raíz?” 343-60.

40 RAH, "Informe resumen de la labor realizada por la Sección Femenina del Movimiento y Proyecto de su actuación futura en la provincia de Sahara,” Madrid, 11 October 1975, NA, Serie Azul, 166.

$41 \quad$ Barona, Los hijos de la nube, 191.

42 See “Administración local y provincial," in Tejero Molina, El Sahara Español, vol. 1: 158-61. In fact, 37 representatives were elected by direct vote and 46 chosen from amongst tribal leaders. Despite being somewhat limited to local and family issues, the institution did have some political clout, serving as an advisory body for the central government. In 1973, in a desperate attempt to expand its political and social base, the Yemáa increased from 82 to 102 members.

$43 \quad$ San Martin, Western Sahara, 54.

44 Caratini, "Du modèle aux pratiques," 43 onwards.

45 López Bargados, Arenas coloniales, 472.

46 Segato, "Género y colonialidad," 17-47.

47 AGMAV, “Dotes matrimoniales,” 12 October 1971, caja 30286, carp 3.

48 These changes had an effect on marriage strategies, as colonial interference tended to consolidate the internal cohesion of the qabila (tribe), leading marriages towards the sheikh who was best at negotiating. On the other hand, those descendants who found themselves in a more favourable situation preferred to marry within the limits of their marriage areas, creating a national network with new elements that were closely related to economic and political power. See Caratini, "Du modèle aux pratiques," 45.

49 Caratini, “A Propos du mariage,” 30-49.

50 It is worth noting the existence of a divorce procedure that adapted the Islamic concept of divorce. According to this principle, a woman could ask her husband for a divorce, and he would be socially obliged to accept. The fact that the majority of marriages were endogamous results in mediation of both the husband's family as well as the wife's, the two of which tended to be related. This mediation sometimes slowed divorce proceedings; in other cases, it could provide women with the possibility of negotiating their situation. Sophie Caratini, in a study on Mauritanian Reguibats, highlights that close families tended to seek mediation in order to avoid divorce. However, this turned out to be more difficult in endogamous marriages. Nonetheless, Juliano, in a study carried out in the Tindouf refugee camps, argues that these endogamous marriages protected women, thanks to mediation from family members. It is possible that these differing opinions are due to the study of different qabilas, as French anthropology has studied southern tribes, while Spanish studies have focused on other, more northern ones. It could also simply be a tool that may or may not be activated, depending on the different cases or contexts. See Caratini, Les Rgaybat and Juliano, La causa saharaui. 51

AGA, “Informe sobre la actitud política de la mujer saharaui,” Laayoune, October 1974, 3(51.19), caja 236. 
53 Bengochea Tirado, "Las mujeres saharauis," 143-59.

54 Despite it being true that the Falangist organisation acted in favour of some Sahrawi close to the SF, and its continued opposition to early marriage, these claims were always dealt with in an informal manner.

$55 \quad$ Morillas, Sahara Occidental, 231.

56 Data which should be treated with caution; in San Martin, Western Sahara, 63.

$57 \quad$ Morillas, Sahara Occidental, 237.

$58 \quad$ Gobierno General del Sahara, Censo, 5.

59 The census included 3,018 “adoptees and poor relatives," the majority of whom were essentially slaves. This group made up approximately 4 percent of the census population. Slavery can be traced back to the sheikhs, who had sufficient economic resources to possess and keep slaves. As the Tomás Bárbulo notes, several sources confirm the complicity of the Spanish authorities in the continuance of this practice; in some cases, military groups even aided in the pursuit of escaped slaves. See Bárbulo, Historia prohibida, 48.

60 Gobierno General del Sahara, Censo, 19.

61 García, Historias del Sahara, 39.

62 Morillas, Sahara Occidental, 184.

63 Caro Baroja, Estudios Saharianos.

64 In the 1974 census, only 17 percent of the inhabitants in the Sahara were considered to be nomads. Approximately 57 percent of the population lived within one of the main urban centres (Laayoune, Villa Cisneros, Smara, and La Güera), and the rest resided in small settlements. See Gobierno General del Sahara, Censo.

65 Rodríguez Esteban and Barrado Timón, "Los procesos de urbanización,” 86.

66 Robles Picón et al., "La poesía saharaui,” 55-76.

67 Awad, “Generaciones literarias,” 29-54.

68 Gimeno Martín, “Ambivalencia y orden colonial,” 151-77.

San Martin, Western Sahara, 47.

Alonso del Barrio, Las Tribus del Sahara.

Morillas, Sahara Occidental, 238; San Martin, Western Sahara, 54.

See Bárbulo, Historia prohibida, 66-95.

Zunes and Mundy, Western Sahara, 91-139.

The historian José Luis Rodríguez points to the importance of ideas of some sectors of the colonial government to prepare independence through a phase of Sahrawi self-government. This was meant to be led by the sheikhs with the support of some young and literate Sahrawis. See Rodríguez, Agonía, traición, huida, part 2.

76 Diego Aguirre, Guerra en el Sáhara, 64-96.

77 Caratini, "La Prison du Temps,” 153-72.

78 Isidoros, "The Silencing of Unifying Tribes," 185.

79 Allan, "Imagining Saharawi Women,” 189-202.

80 Fiddian-Qasmiyeh, “'Ideal’ Refugee Women,” 64-84.

81 Caratini, "La Prison du Temps,” 163.

82 Balandier, "The Colonial Situation."

83 Loomba, Colonialism/Postcolonialism, 39.

84 Robinson, "Non-European Foundations," 117-42.

Correale, “La narración de la historia,” 151-68.

López Bargados, “El Sahara ante su espejo,” 133-50. 